Zusammenfassung. Läsion, Operation und Fixation des Kniegelenkes führen zu Muskelatrophie, Gelenksteife, Bandschwäche und Knorpelschäden. Das Resultat von experimentellen Untersuchungen: Nach Bandoperation kann das Kniegelenk zwischen 20 und $60^{\circ}$ Beugung bewegt werden, ohne die Naht oder Plastik zu gefährden. Ergebnisse von 80, 5-6 Wochen funktionell mit Bewegungsgips nachbehandelten Fällen: Freie Beweglichkeit nach 3 Monaten bei 64, nach 6 Monaten bei 73 Patienten. Eintritt der Arbeitsfähigkeit durchschnittlich 7,2 Wochen nach Gipsentfernung.

Schlüsselwörter: Knie - Bänder - Bewegungsgips.

\title{
176. Das Rezidivulcus nach Magenresektion
}

\author{
G. Heberer, V. Zumtobel, J. Witte und G. Feifel \\ Chirurgische Klinik der Universität München
}

\section{Recurrent Ulcer after Gastrectomy}

Summary. In 195 patients treated by regastrectomy and truncular vagotomy a complication rate of 19.4 percent and a mortality of 8.4 percent were observed. In 44 patients treated by truncular or selective vagotomy only, the complication rate is 9.2 percent and mortality so far nil. Further recurrences were recorded in 4.2 percent after regastrectomy and truncular vagotomy and in 16.6 percent after truncular vagotomy only. No recurrence has yet been determined after careful selective vagotomy. The higher recurrence rate is attributed to variations in the continuation of the vagus trunks. Selective vagotomy is recommended as a low-risks successful method.

Key words: Regastrectomy: Recurrence - Regastrectomy: Complication rate - Vagotomy, selective: Stomach.

Zusammenfassung. Bei 195 mit Nachresektion und trunkulärer Vagotomie behandelten Patienten betrug die Komplikationsrate 19,4\% und die Op.-Letalität 8,4\%. 44 nur mit trunkulärer bzw. selektiver Vagotomie behandelte Kranke zeigten eine Komplikationsrate von 9,2\% und bisher keine Letalität. Erneute Rezidive wurden nach Nachresektion und trunkulärer Vagotomie in 4,2\%, nach trunkulärer Vagotomie allein in $16,6 \%$ und nach sorgfältiger selektiver Vagotomie bisher nicht beobachtet. Die höhere Rezidivrate nach trunkulärer Vagotomie wird auf Variationen im Verlauf der Vagusstämme zurückgeführt und die selektive Vagotomie als risikoarme und erfolgssichere Methode empfohlen.

Schlüsselwörter: Nachresektion - Komplikationsrate - Rezidive - selektiv-gastrale Vagotomie. 